\title{
Different community structure and temperature optima of heterotrophic picoplankton in various regions of the Southern Ocean
}

\author{
Meinhard Simon ${ }^{1, *}$, Frank Oliver Glöckner ${ }^{2}$, Rudolf Amann ${ }^{2}$ \\ ${ }^{1}$ Institute for Chemistry and Biology of the Marine Environment, University of Oldenburg, PO Box 2503, \\ D-26111 Oldenburg, Germany \\ ${ }^{2}$ Max-Planck-Institute for Marine Microbiology, Celsiusstr. 1, D-28359 Bremen, Germany
}

\begin{abstract}
The temperature control of the growth of heterotrophic picoplankton was studied in the Southern Ocean along a transect befween the Polar Front $\left(49^{\circ} \mathrm{S}\right)$ and the shelf ice edge at $70^{\circ} \mathrm{S}$ in the austral summer. Growth was measured by thymidine and leucine incorporation applying the dual-label approach. Psychrotolerant or mesophilic communities with a growth optimum of $>18^{\circ} \mathrm{C}$ were present in surface waters at the Polar Front at an in situ temperature of 4 to $5^{\circ} \mathrm{C}$. Further south in surface waters of the Antarctic circumpolar current (ACC), in the marginal ice zone and at the shelf ice edge, psychrophilic communities with growth optima of 11 and 4 to $8^{\circ} \mathrm{C}$, respectively, were present. Growth at the ambient temperature of $\mathrm{ca} 0^{\circ} \mathrm{C}$ or slightly below was reduced. By in situ hybridization with fluorescent rRNA-targeted oligonucleotide probes, between 63 and $96 \%$ of all DAPI-stainable picoplankton cells were identified as Bacteria whereas Archaea were never detected. Cells belonging to the Cytophaga/Flavobacterium cluster were most abundant from all bacterial groups tested $(\alpha-, \beta-$, and $\gamma$-subclass of Proteobacteria, Cytophaga/Flavobacterium cluster) and comprised $20 \%$ of DAPI counts at the Polar Front and $40 \%$ in the ACC. In the marginal ice zone during a bloom of Phaeocystis sp. they even comprised $72 \%$. $\gamma$-subclass proteobacteria accounted for $<1 \%$ of DAPI counts at the Polar Front and for 7 to $9 \%$ further south. $\alpha$-subclass proteobacteria never exceeded $1 \%$ and $\beta$-subclass proteobacteria were not detected at all. The results indicate that different communities of heterotrophic picoplankton established along the transect from the Polar Front south to the marginal ice zone as shown by the reduction of the temperature optima and coinciding with a change in the community structure and a pronounced dominance of bacteria of the Cytophaga/Flavobacterium cluster in the psychrophilic communities.
\end{abstract}

KEY WORDS: Heterotrophic picoplankton - Psychrophilic bacteria - Temperature In situ hybridization . Oligonucleotide probes $\cdot$ Southern Ocean

\section{INTRODUCTION}

Heterotrophic picoplankton has been identified as one of the major trophic compartments in processing phytoplankton primary production in the world's oceans. As a mean for many regions including the Pacific, Atlantic, Indian and Southern Oceans, the ratios of picoplankton secondary production over primary production in the mixed layer range between 0.09 and 0.40 even though lower and higher ratios can

\footnotetext{
•E-mail: m.simon@icbm.de
}

occur for short periods (Cota et al. 1990, Ducklow \& Carlson 1992, Ducklow et al. 1993, Kirchman et al. 1993, Lochte et al. 1997). Interestingly, the ratios in the colder areas of the oceans such as in the subarctic Pacific and the Southern Polar Front are at the lower end, which supports the idea that temperature may limit picoplankton secondary production more than primary production at low temperature (Pomeroy \& Deibel 1986). On the other hand, ratios of picoplankton secondary production over primary production in cold areas such as in the Antarctic circumpolar current ( $A C C)$ have also been reported to be elevated at low rates of primary production or because of a temporal 
uncoupling of these 2 processes (Cota et al. 1990 Billen \& Becquevort 1991, Lochte et al. 1997).

A key question for understanding the relationship between picoplankton secondary production and primary production in the cold is how the heterotrophic picoplankton communities are adapted to the low temperature, in the sense whether psychrophilic, psychrotolerant or mesophilic communities sensu Morita (1975) establish and dominate the consumption of organic matter. This question was addressed in various studies which determined picoplankton secondary production or growth rates as a function of temperature. Most studies found that the optimum temperature of rates of production or growth was above the in situ temperature irrespective of whether psychrophilic or psychrotolerani communities were present (Azam et al. 1981, Hodson et al. 1981, Kirchman et al. 1993, Lochte et al. 1994).

An important implication of these findings leads to the hypothesis that regions with a pronounced difference in the temperature optimum of heterotrophic picoplankton growth exhibit a different community structure. This hypothesis, however, has not been tested. Various studies in different oceanic provinces provide some evidence for it. Using $16 \mathrm{~S}$ rRNA-targeted oligonucleotide probes, differences in the composition of auto- and heterotrophic picoplankton in the Sargasso Sea, the coastal northwest Pacific and the Southern Ocean, regions with pronounced differences in the temperature regime, have been found (Giovannoni et al. 1990, DeLong et al. 1994). Very little, however, is known about the quantitative composition of the heterotrophic picoplankton in marine environments, even though a high qualitative genetic diversity of picoplankton phylotypes and a substantial fraction of Archaea in particular in cold environments have been found (Fuhrman et al. 1993, DeLong et al. 1994, Mullins et al. 1995, Massana et al. 1998, Murray et al. 1998). An ideal instrument for such studies is the in situ hybridization by rRNA-targeted fluorescent oligonucleotide probes (Amann et al. 1995, Glöckner et al. 1996), which recently has also been applied to coastal heterotrophic picoplankton (Ouverney \& Fuhrman 1997)

We examined the temperature optima of heterotrophic picoplankton production at the Polar Front, in the $\mathrm{ACC}$ and in the marginal ice zone of the Southern Ocean. In the same regions and mostly at the same locations we also examined the composition of the heterotrophic picoplankton by in situ hybridization with rRNA-targeted fluorescent oligonucleotide probes.

\section{MATERIALS AND METHODS}

This study was performed during the cruise ANT XIII/2 of the RV 'Polarstern' from Cape Town, South Africa, to the German Neumeyer base and back to Cape Town. Samples were collected at the Polar Front, in the $\mathrm{ACC}$, the marginal ice zone, and directly at the shelf ice edge close to the Neumeyer base. For the dates and exact locations see Table 1 . Samples south of the Polar Front, and samples for measurements of picoplankton growth at the Polar Front were taken from the surface with a bucket. Measurements of picoplankton growth started within $30 \mathrm{~min}$ of sampling. For in situ hybridization with fluorescent oligonucleotide probes samples at the Polar Front were taken with 121 GoFlo bottles mounted on a rosette on 25 December 1995 at $50^{\circ} 28.62^{\prime} \mathrm{S}, 08^{\circ} 08^{\prime} 82 \mathrm{E}$ at $60 \mathrm{~m}$ and on 29 December 1995 at $49^{\circ} 29.40^{\prime} \mathrm{S}, 11^{\circ} 23.58^{\prime} \mathrm{E}$ at 20 and $40 \mathrm{~m}$. From the bottles subsamples were withdrawn into acid-rinsed 1 l-polyethylene flasks, kept at in situ temperature and further processed within $2 \mathrm{~h}$. Samples for in situ hybridization south of the Polar Front were also taken with a bucket from the surface.

To examine the temperature optima of heterotrophic picoplankton growth experiments were carried out in which this parameter was measured at various temperatures between -0.5 or 0 and 12 to $20^{\circ} \mathrm{C}$. In the experiments at the Polar Front in early January the highest temperature tested was $12^{\circ} \mathrm{C}$ whereas on 19 January the range was extended to $20^{\circ} \mathrm{C}$. The incubation temperatures were controlled carefully such that they

Table 1 Locations, dates of the experiments, in situ temperatures at the sampling sites in the Southern Ocean, numbers and in situ rates of biomass production of heterotrophic picoplankton. ACC: Antarctic circumpolar current; MIZ: marginal ice zone

\begin{tabular}{|c|c|c|c|c|c|}
\hline \multirow[t]{2}{*}{ Region } & \multirow[t]{2}{*}{ Location } & \multirow{2}{*}{$\begin{array}{l}\text { Date } \\
\text { (1996) }\end{array}$} & \multirow{2}{*}{$\begin{array}{l}\text { Tem- } \\
\text { perature } \\
\left({ }^{\circ} \mathrm{C}\right)\end{array}$} & \multicolumn{2}{|c|}{ Picoplankton } \\
\hline & & & & $\begin{array}{l}\text { Numbers } \\
\left(10^{5} \mathrm{ml}^{-1}\right)\end{array}$ & $\begin{array}{l}\text { Production } \\
\left(\text { ng C } ~^{-1} h^{-1}\right)\end{array}$ \\
\hline \multirow[t]{3}{*}{ Polar Front } & $\begin{array}{l}49^{\circ} 42.15^{\prime} \mathrm{S} \\
10^{\circ} 18.32^{\prime} \mathrm{E}\end{array}$ & $3 \mathrm{Jan}$ & 4.92 & 4.88 & 56.75 \\
\hline & $\begin{array}{l}49^{\circ} 45.00^{\prime} \mathrm{S} \\
10^{\circ} 30.04^{\prime} \mathrm{E}\end{array}$ & 4 Jan & 4.11 & 5.29 & 47.67 \\
\hline & $\begin{array}{l}49^{\circ} 23.50^{\prime} \mathrm{S} \\
10^{\circ} 58.06^{\prime} \mathrm{E}\end{array}$ & $19 \mathrm{Jan}$ & 5.04 & 8.11 & 145.55 \\
\hline $\mathrm{ACC}$ & $\begin{array}{l}58^{\circ} 56.52^{\prime} \mathrm{S} \\
03^{\circ} 58.44^{\prime} \mathrm{E}\end{array}$ & $9 \mathrm{Jan}$ & 0.11 & 1.51 & 10.30 \\
\hline MIZ & $\begin{array}{l}68^{\circ} 50.57^{\prime} \mathrm{S} \\
06^{\circ} 01.09^{\prime} \mathrm{E}\end{array}$ & $11 \mathrm{Jan}$ & 0.12 & 3.88 & 36.11 \\
\hline Shelf ice edge & $\begin{array}{l}70^{\circ} 29.89^{\prime} \mathrm{S} \\
08^{\circ} 15.47^{\prime} \mathrm{E}\end{array}$ & $13 \mathrm{Jan}$ & -1.67 & 1.08 & 4.89 \\
\hline
\end{tabular}


remained within $\pm 0.5^{\circ} \mathrm{C}$ during the incubation time. Rates of biomass production and cell multiplication were determined by the incorporation of ${ }^{14} \mathrm{C}$-leucine (Kirchman et al. 1985 , Simon \& Azam 1989) and ${ }^{3} \mathrm{H}$-thymidine (TdR, Fuhrman \& Azam 1980) using the dual-label approach (ChinLeo \& Kirchman 1988). Subsamples of 10 or $20 \mathrm{ml}$ were withdrawn into clean polystyrene test tubes. Triplicates and a Formalin-killed control were labelled with ${ }^{14} \mathrm{C}$-leucine $11.5 \mathrm{GBq}$ $\mathrm{mmol}^{-1}$, Amersham) and ${ }^{3} \mathrm{H}$-thymidine (3 TBq mmol ${ }^{-1}$, Amersham, diluted 1:5 with non-labelled $\mathrm{TdR}$ ) at a final concentration of $10 \mathrm{nM}$ each. Incubation at the various temperatures was in the dark and stopped after 4 to $6 \mathrm{~h}$ by adding Formalin ( $2 \%$ final concentration). Prior to the addition of the radiolabel the samples were preadjusted to the incubation temperatures for $30 \mathrm{~min}$. After fixation samples were filtered onto $0.45 \mu \mathrm{m}$ nitrocellulose filters (Sartorius), rinsed with ice-cold particle-free seawater and extracted with ice-cold $5 \%$ trichloroacetic acid (TCA) for $5 \mathrm{~min}$. After rinsing the extracted filters twice with ice-cold $5 \%$ TCA, the filters were dissolved with ethylacetate and radioassayed by liquid scintillation counting. Biomass production was calculated from leucine incorporation rates by using a conversion factor of $3.0 \mathrm{~kg} \mathrm{C} \mathrm{(mol} \mathrm{leucine)})^{-1}$ (Simon \& Azam 1989, Bjørnsen \& Kuparinen 1991). To convert TdR incorporation into rates of cell multiplication a conversion factor of $1.4 \times 10^{18}$ cells (mol TdR) ${ }^{-1}$ (Bjørnsen \& Kuparinen 1991) was used.

Temperature optima were definded as those temperatures or temperature ranges at which rates of biomass production and cell multiplication were highest or within $95 \%$ of the highest rate. Responses of these rates to increasing temperatures were calculated on the basis of their respective $Q_{10}$ values calculated as $Q_{10}=\left(K_{1} / K_{2}\right)^{10 /\left(t_{1}-t_{2}\right)}$ (Sherr \& Sherr 1996). $K_{1}$ and $K_{2}$ are rates at temperatures $t_{1}$ and $t_{2}\left(\right.$ in ${ }^{\circ} \mathrm{C}$ ), where $t_{1}>t_{2}$. The temperature ranges for which $Q_{10}$ was calculated are given in Table 2.

In situ hybridization with fluorescent rRNA-targeted oligonucleotide probes was done according to Glökner et al. (1996). The samples were filtered onto $0.2 \mu \mathrm{m}$ Nuclepore filters and fixed by overlaying the filters with $3 \mathrm{ml}$ of a freshly prepared, PBS-buffered ( $\mathrm{pH} 7.2$ ) $4 \%$ paraformaldehyde solution for $30 \mathrm{~min}$. Thereafter, the filters were washed with Milli-Q water and stored frozen at $-20^{\circ} \mathrm{C}$ until hybridization after 4 mo. The hybridization protocol as described in Glöckner et al.
(1996) was applied and the following group-specific oligonucleotide probes were used: EUB338 for Bacteria (Amann et al. 1990), ALF968 for $\alpha$-subclass proteobacteria (Neef 1997), BET42a and GAM42a for $\beta$ - and $\gamma$-subclass proteobacteria (Manz et al. 1992), and CF319a for members of the Cytophaga/Flavobacteria cluster (Manz et al. 1996). In addition, we applied the Archaea-specific probes ARCH344 and ARCH915 (Amann et al. 1995). The probes were linked to the $\mathrm{N}$-hydroxysuccinimidester of the carbocyanine CY3 as the fluorochrome. The hybridization procedure includes a final staining with DAPI. Cells were viewed using an Axioplan epifluorescence microscope (Zeiss, Jena, Germany) and the filter sets Zeiss 01 for DAPI and Chroma HQ41007 (Chroma Tech. Corp. Brattleboro, VT, USA). For each sample 2 replicates were counted and 10 to 20 view fields with at least 500 cells per sample. All counts were corrected by subtracting the counts obtained with a negative control (NON338) which never exceeded $1 \%$

\section{RESULTS}

The in situ temperature at the Polar Front ranged between 4 and $5^{\circ} \mathrm{C}$ and decreased further south. In the ACC it was around $0^{\circ} \mathrm{C}$ and dropped to below $-1^{\circ} \mathrm{C}$ in the marginal ice zone close to the shelf ice edge (Table 1, Fig. 1). At the Polar Front the top 40 to $60 \mathrm{~m}$ (mixed layer) were well mixed as indicated by temperature profiles, numbers and production of heterotrophic picoplankton which agreed within $25 \%$ between the surface and $60 \mathrm{~m}$ depth. At the Polar Front 


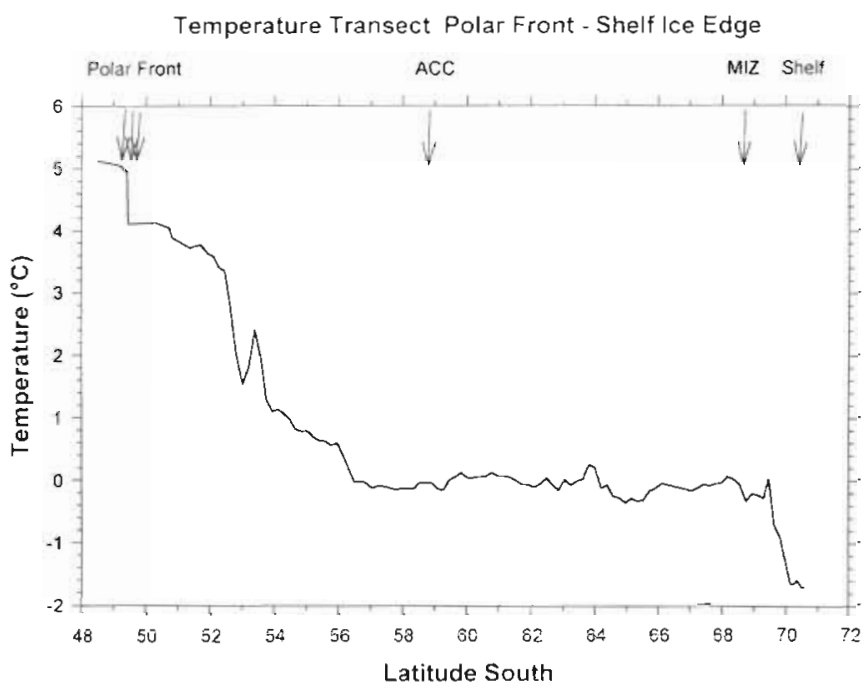

Fig. 1. Transect of temperature at $5 \mathrm{~m}$ between the Polar Front and the shelf ice edge recorded between 8 and 12 January 1.996. Temperature was measured online with a sensor on the RV 'Polarstern' The arrows indicate the locations of the experiments at the Polar Front, the Antarctic circumpolar current (ACC), the marginal ice zone (MIZ), and the shelf ice edge (Shelf)

rates of heterotrophic picoplankton biomass production and cell multiplication continuously increased with temperature from 0 to 11 and $20^{\circ} \mathrm{C}$ (Fig. 2A). The 2 experiments in early January showed similar re- sponses to increasing temperature whereas on 19 January growth increased much faster with temperature. On 19 January picoplankton numbers and in situ rates of biomass production were much higher than in early January (Table 1) even though the vertical distribution of numbers and production rates in the upper $60 \mathrm{~m}$ were not different in early and on 19 January. Interestingly, the patterns of temperature response in the ACC and the marginal ice zone were quite different despite similar in situ temperatures (Table 1, Fig, 2B). In the ACC picoplankton growth had an optimum at $11^{\circ} \mathrm{C}$ and decreased above this temperature. Between 0 and $4^{\circ} \mathrm{C}$ increase with temperature was much stronger than between 4 and $11^{\circ} \mathrm{C}$. In fact, rates at 4 and $7^{\circ} \mathrm{C}$ were not statistically different both for biomass production and cell multiplication (Student's t-test, $\mathrm{p}<$ $0.01)$. In the marginal ice zone rates of biomass production were highest in the temperature range of 4 to $8^{\circ} \mathrm{C}$ whereas those of cell multiplication were in the range of 8 to $11^{\circ} \mathrm{C}$ (Fig. 2B). The rate of increase in biomass production, which was between 0 and $2.4^{\circ} \mathrm{C}$ at this location, was similar to that, between 0 and $4^{\circ} \mathrm{C}$, in the ACC whereas that of cell multiplication rates was even higher (Table 2). At the shelf ice edge picoplankton growth between -0.5 and $2^{\circ} \mathrm{C}$ remained constant at very low rates as the slopes of increase of picoplankton growth within this temperature range were not statistically different from zero (Table 2). Growth only

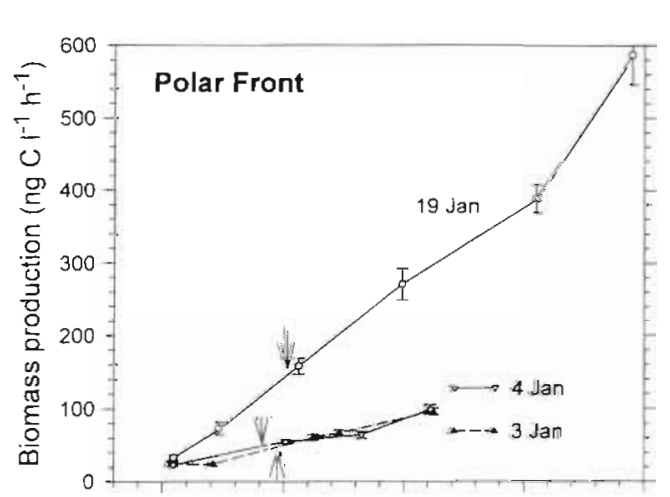

A
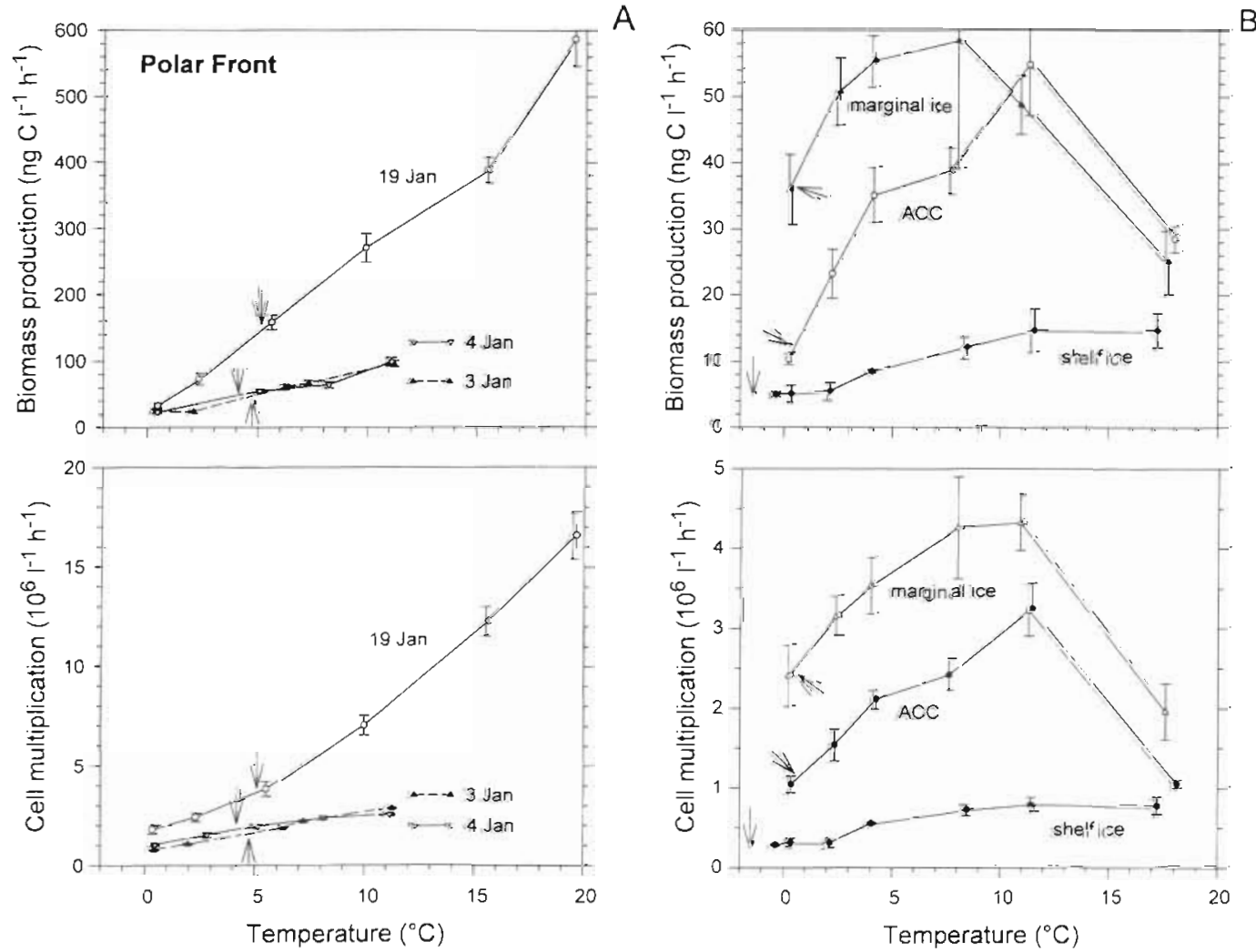

B

Fig. 2. Biomass produc tion and cell multiplication of heterotrophic picoplankton \pm standard deviation at various temperatures at (A) the Polar Front and (B) in the Antarctic circumpolar current (ACC), the marginal ice zone, and at the shelf ice edge. Arrows indicate the in situ temperature. If standard deviation is not visible, it is smaller than the symbols. For the exact locations of the experiments and in situ temperatures see Table 1 
increased above $2^{\circ} \mathrm{C}$ and was highest in the range of 11 to $17^{\circ} \mathrm{C}$ (Fig. 2B).

$Q_{10}$ values, calculated for the entire temperature ranges and various sections with fairly continuous increase, varied from 1.3 to 34.7 (Table 2). They were highest at the Polar Front for the entire range tested and at the shelf ice edge for the range between 2 and $4^{\circ} \mathrm{C}$. The lowest values, 1.3 to 1.9 , were recorded in the marginal ice zone and at the shelf ice edge for the ranges between 2 and 8 , and -0.5 and $2^{\circ} \mathrm{C}$, respectively. $Q_{10}$ values of biomass production and cell multiplication agreed particularly well in the ACC and the marginal ice zone. In $67 \%$ of the experiments, though, the $Q_{10}$ of biomass production was higher than that of cell multiplication. This finding, that biomass production increases more with temperature than cell division, is consistent with similar observations by Shiah \& Ducklow (1994) and Tibbles (1997).

In situ hybridization with oligonucleotide probes showed a high detection rate in all samples (Figs. 3 \& 4). Between 61 and $96 \%$ of all picoplankton cells stainable with DAPI hybridized with the probe EUB338. The probes specific for Archaea ARCH344 and ARCH915 did not give any positive signals in the samples examined. Samples for in situ hybridization at the Polar Front were not collected at the exact locations of the temperature shift up experiments but at stations very close to them. Because all results of in situ hybridization at the Polar Front were in close agree-

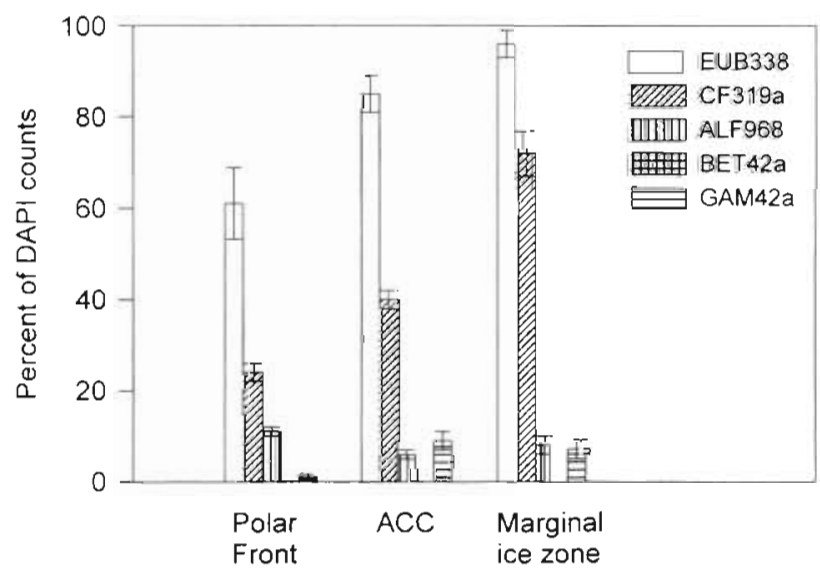

Fig. 3. Community structure of the heterotrophic picoplankton as determined by in situ hybridization with rRNA-targeted fluorescent oligonucleotide probes at the Polar Front $(40 \mathrm{~m})$, in the Antarctic circumpolar current (ACC, surface) and the marginal ice zone (surface; mean values \pm standard deviation). Probe data are given as percent of cells detectable after staining with DAPI. For the exact locations of the experiments and dates see Table 1. Specifications of the probes are as follows: EUB338 for Bacteria; CF319a for the Cytophagal Flavobacteria cluster; ALF968 for $\alpha$-subclass proteobacte-

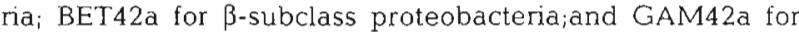
$\gamma$-subclass proteobacteria ment, we only include 1 example of $40 \mathrm{~m}$ of the station $49^{\circ} 29.40^{\prime} \mathrm{S}, 11^{\circ} 23.40^{\prime} \mathrm{E}$ in Fig. 3. At this station $24 \%$ (range of all 3 stations: 19 to $24 \%$ ) of the DAPI-stainable cells $\left(9.0 \times 10^{8} \mathrm{l}^{-1}\right)$ were identified as belonging to the Cytophaga/Flavobacterium cluster, $11 \%$ to $\alpha$-subclass proteobacteria (range of all 3 stations: 4 to $11 \%$ ) and $1 \%$ to $\gamma$-subclass proteobacteria (Fig. 3). Also, at the other 2 stations $\gamma$-subclass proteobacteria comprised not more than $1 \%$ of DAPI-stainable cells. $\beta$-subclass proteobacteria were not detected at the Polar Front or at other locations. In fact, we did not find any signals of the probe BET42a in any of the samples. South of the Polar Front the proportion of bacteria belonging to the Cytophaga/Flavobacterium cluster continuously increased. In the ACC $40 \%$ of the DAPIstainable cells were identified as members of this cluster. In the marginal ice zone, where we collected samples at the southern edge of an intense bloom of Phaeocystis sp. with chlorophyll concentrations of 1.5 to $2.0 \mathrm{\mu g} \mathrm{l}^{-1}$ (U. Bathmann unpubl. results), as much as $72 \%$ of the DAPI-stainable cells belonged to the Cytophaga/Flavobacterium cluster (Figs. $3 \& 4$ ). Also, the proportion of $\gamma$-subclass proteobacteria increased in the ACC and the marginal ice zone but did not exceed $9 \%$ The proportion of $\alpha$-subclass proteobacteria remained fairly similar in all areas sampled. At the Polar Front, in the ACC and the marginal ice zone 47 , 65 , and $91 \%$, respectively, of the cells detected with the probe EUB338 could be characterized with the group-specific probes applied.

\section{DISCUSSION}

The heterotrophic picoplankton in the various regions of the Southern Ocean exhibited pronounced differences with respect to growth control by temperature. The optimum temperature continuously decreased from $20^{\circ} \mathrm{C}$ at the Polar Front to $11^{\circ} \mathrm{C}$ in the $\mathrm{ACC}$ and 4 to $8^{\circ} \mathrm{C}$ in the marginal ice zone. Even though at the shelf ice edge lowest rates of biomass production and cell multiplication were measured at in situ temperature, the optimum temperature was in the range of 11 to $17^{\circ} \mathrm{C}$ and thus higher than in the marginal ice zone. Hence, the results indicate that at the Polar Front facultatively psychrophilic, psychrotolerant or mesophilic picoplankton communities sensu Morita (1975) dominated, whereas further south obligately psychrophilic communities with different temperature optima were present. In all regions, the optimum temperature for bacterial growth was above the in situ temperature.

Several other studies carried out in cold oceanic regions also found that the optimum growth temperature of the heterotrophic picoplankton was above the 


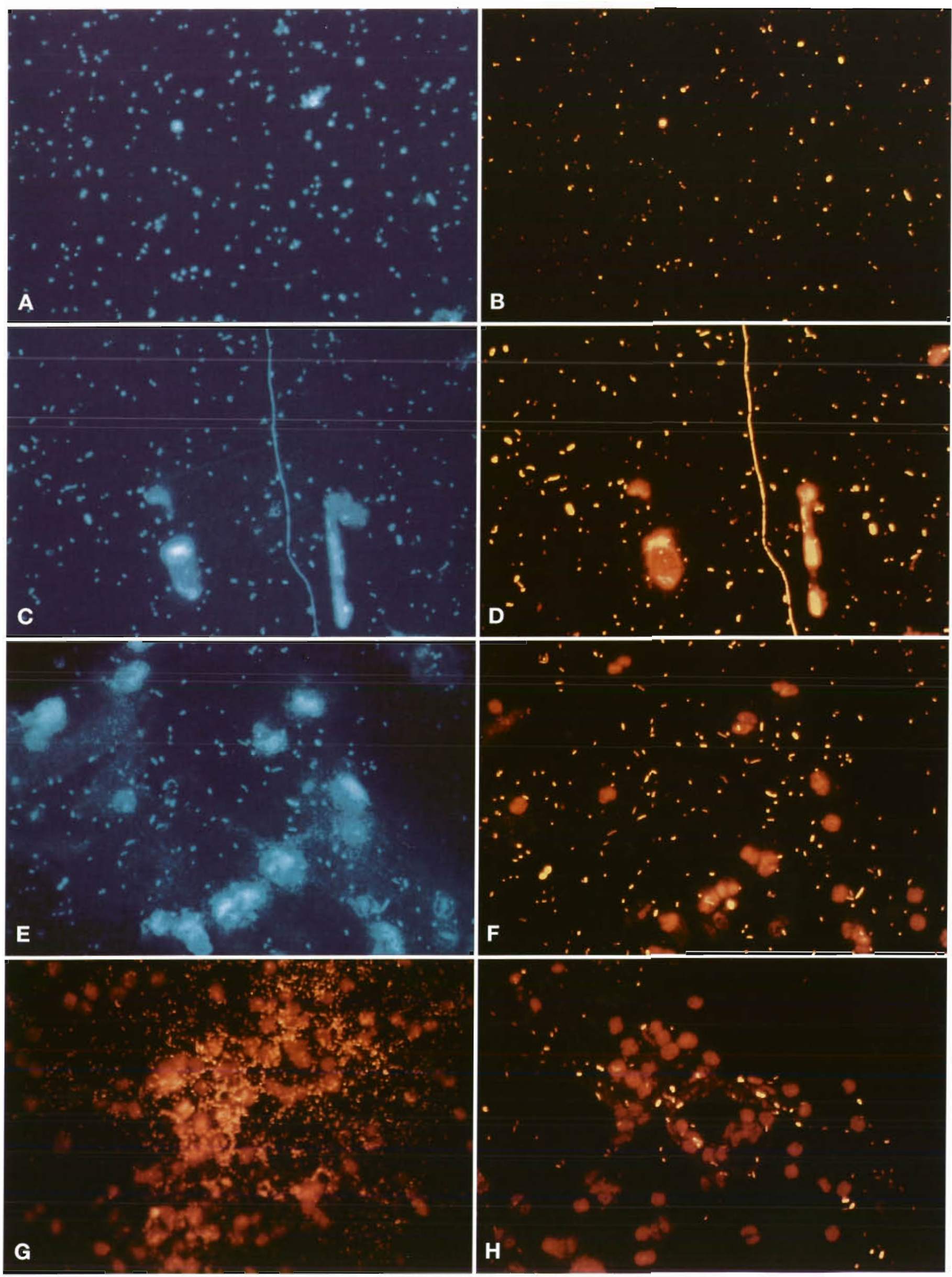


Fig. 4. Colour micrographs of picoplankton cells stained by DAPI (A, C, E) and by in situ hybridization with CY3-labeled rRNAtargeted oligonucleotide probes (B, D, F, G, H). (A, B) Polar Front; (C, D) ACC; $(E, F, G, H)$ marginal ice zone with Phaeocystis cells. (A to F) show identical viewfields stained by DAPI and the probe EUB338. (G) shows Cytophaga/Flavobacteria stained by probe CF319a and (H) shows $\alpha$-subclass proteobacteria stained by probe ALF968

in situ temperature (Azam et al. 1981, Hodson et al. 1981, Kirchman et al. 1993, Lochte et al. 1994). Whereas this notion is not surprising when mesophilic or psychrotolerant communities are present, it may be unexpected that psychrophilic communities also always exhibit a higher optimum than in situ growth temperatures. A possible explanation may be that psychrophilic microbes do not optimize growth or biomass production rates at the fairly low in situ temperatures but the growth yield. Morita (1975) reported that for one psychrophilic bacterial isolate grown at the usually high substrate concentrations applied in bacterial pure culture studies the growth yield was maximized below the optimum temperature for growth. Whether this notion is a general phenomenon of psychrophiles and also true at low substrate concentrations such as under ambient conditions in situ remains to be examined.

Interestingly, the temperature optimum of biomass production and cell multiplication of heterotrophic picoplankton at the Polar Front was not below $20^{\circ} \mathrm{C}$, and thus at least 8 to $12^{\circ} \mathrm{C}$ higher than further south in the $\mathrm{ACC}$ and the marginal ice zone, even though the in situ temperatures in all 3 regions were $5^{\circ} \mathrm{C}$ and below. Unfortunately, we limited the temperature range tested in early January at the Polar Front from 0 to $11^{\circ} \mathrm{C}$ but we assume that the optimum was not different than 2 wk later. Kirchman et al. (1993) in the subarctic Pacific also found that heterotrophic picoplankton growth exhibited a temperature optimum of $20^{\circ} \mathrm{C}$ whereas the in situ temperature was only $6^{\circ} \mathrm{C}$. Studies covering seasons with greatly varying in situ temperatures in the Chesapeake Bay, the Baltic Sea and small freshwater lakes also reported that the optimum growth temperature of heterotrophic picoplankton was fairly constant between 20 and $25^{\circ} \mathrm{C}$ and was independent of the in situ temperature except for a short period in summer at highest in situ temperatures (Lovell \& Konopka 1985, Autio 1992, Morris \& Lewis 1992, Shiah \& Ducklow 1994, Coveney \& Wetzel 1995). Simon \& Wünsch (1998), however, found that in the large and deep Lake Constance, Germany, in situ and optimum growth temperatures of heterotrophic picoplankton in the upper $10 \mathrm{~m}$ usually differed by not more than $5^{\circ} \mathrm{C}$ despite in situ temperatures ranging from 5 to $23^{\circ} \mathrm{C}$. In accordance with these reports and the present study we hypothesize that temperatureadapted heterotrophic picoplankton communities establish only when thermal conditions for mesophilic communities are favorable or, in the case of psychrophilic communities, in systems with little largescale mixing of different water masses and/or a residence time of the water masses far exceeding the generation time of the ambient picoplankton. Such conditions are given in the ACC and the marginal ice zone, and in large lakes with a pronounced pelagic zone such as Lake Constance but not at the Polar Front or in other frontal systems including estuaries and most small lakes.

A conclusion from the cited studies is that temperature can control growth of heterotrophic picoplankton in 2 different ways, either directly when growth is a positive function of temperature, or indirectly by selecting the establishment of a community well adapted to the ambient temperature. Both types of control have specific implications for the transfer of organic matter in the food web which are different at different in situ temperatures, e.g. in cold $\left(<5^{\circ} \mathrm{C}\right)$ or warmer environments. We note that, in addition, availability of and preferences for organic substrates and inorganic nutrients may also control the growth of heterotrophic picoplankton (Morris \& Lewis 1992, Coveney \& Wetzel 1995, Schweitzer \& Simon 1995). Further, the temperature control of phytoplankton, proto- and mesozooplankton growth relative to that of heterotrophic picoplankton may also be important in controlling the transfer of organic matter in the food web at various temperature ranges. Pomeroy \& Deibel (1986) found evidence that below $4^{\circ} \mathrm{C}$ picoplankton secondary production (PSP) is more limited by temperature than primary production (PP), reducing the ratio of PSP/PP. Examining substrate utilization of bacteria at low temperatures in more detail. Wiebe et al. (1992, 1993) found that psychrotolerant bacterial isolates grew faster at high than at low substrate concentrations at the minimum growth temperature but still at substantially lower growth rates than at $15^{\circ} \mathrm{C}$ or above. On the other hand, Harder \& Veldkamp (1971) reported that a psychrophilic bacterial isolate with a growth optimum at $14.5^{\circ} \mathrm{C}$ grew faster between -2 and $+10^{\circ} \mathrm{C}$ both at low and at high substrate concentrations than a mesophilic isolate with a growth optimum at $30^{\circ} \mathrm{C}$. These findings suggest that mesophilic and psychrotolerant bacteria are more substrate-limited at low than at high temperatures as compared to psychrophilic bacteria. They imply that if psychrotolerant bacteria are prominent in heterotrophic picoplankton communities substrate limitation at low temperature 
becomes relatively more important than if psychrophilic bacteria dominate. The relatively low ratios of PSP/PP in cold oceans of $<0.15$ (Cota et al. 1990, Kirchman et al. 1993, Lochte et al. 1997) further suggest that growth and production of heterotrophic picoplankton communities in these environments are limited more by temperature than PP. This effect will be more pronounced if mesophilic bacteria dominate the community such as at the Polar Front (Lochte et al. 1997, this study) or in the subarctic Pacific (Kirchman et al. 1993). We further hypothesize that if a picoplankton community that is well adapted to the ambient temperature, whether psychrophilic or mesophilic, is established and the transfer processes of DOM are unchanged, the ratio of PSP/PP should be the same in cold as well as in temperate and warm environments.

In situ hybridization with fluorescent $r$ RNA-targeted oligonucleotide probes is a powerful tool for characterizing microbial communities in aquatic environments. So far, this method has been successfully applied to characterize bacterial communities in lakes, on lake snow aggregates, on activated sludge and in coastal waters (Wagner et al. 1993, Alfreider et al. 1996, Glöckner et al. 1996, Weiss et al. 1996, Ouverney \& Fuhrman 1997, Pernthaler et al. 1998). Our results demonstrate that this method is also suitable for characterizing picoplankton assemblages in oceanic environments such as the Southern Ocean. Between 63 and $96 \%$ of the DAPI-stainable cells were detected as Bacteria with the highest proportion in the marginal ice zone. From the Polar Front to the marginal ice zone the proportion of cells of the Cytophaga/Flavobacterium cluster increased from 20 to $72 \%$ of DAPI counts. Interestingly, the highest proportion of Cytophaga/Flavobacterium was detected in a Phaeocystis bloom in the marginal ice zone. Obviously, the mucus- and substrate-rich environment of this colonial algae, which often dominates the phytoplankton in the early austral spring (Kang \& Fryxell 1993, Putt et al. 1994, Karentz \& Spero 1995), favors the establishment of homogeneous blooms of psychrophilic Cytophaga/Flavobacterium populations.

The changes in the structure of the bacterial community along the transect coincided with the decrease of the optimum temperature of picoplankton growth (see above), indicating that the psychrophilic communities south of the Polar Front were increasingly dominated by bacteria of the Cytophaga/Flavobacterium cluster. At the Polar Front, samples for the temperature shiftup experiments and the analysis of the structure of the picoplankton community were not taken on the same day and at the same depth. The 3 samples from 20,40 and $60 \mathrm{~m}$ depths which we used to analyze community structure, however, exhibited only minor variations, suggesting that they were representative of the mixed layer and the given seasonal situation at the Polar Front including presumably also on 19 January, for which we had only data on the temperature shift-up experiments and total picoplankton numbers and growth. Growth was substantially higher than 2 to 3 wk before, which may explain the different temperature response of the picoplankton growth as compared to early January. We also assume that the temperature response of the picoplankton growth between the surface and the bottom of the mixed layer was not different and thus our findings with surfce samples representative for the picoplankton community of the entire mixed layer.

Our findings on the composition of the picoplankton community are consistent with observations that the ubligately psychophilic bacteria isolated in various types of ice in the Southern Ocean are frequently members of the Cytophaga/Flavobacterium cluster (Helmke \& Weyland 1995, Bowman et al. 1997, E. Helmke pers. comm). These findings also show that in the austral summer the heterotrophic picoplankton communities in surface waters of the Southern Ocean south of the Polar Front consist predominantly of bacteria of known phylogenetic lineages. Microbes of lineages newly discovered, e.g. members of the Archaea, have been detected in other oceanic regions (Giovannoni et al. 1990, Fuhrman et al. 1993, Mullins et al. 1995) and also in the Southern Ocean, but mainly in winter and in deeper water layers and with decreasing proportions towards summer and phytoplankton blooms (DeLong et al. 1994, Massana et al. 1998, Murray et al. 1998). Archaea obviously did not play a prominent role in the surface waters of the regions of the Southern Ocean we studied during the austral summer.

An interesting result was that we did not detect any signal of $\beta$-subclass proteobacteria in any of the samples. No signal of this phylogenetic analyzing $16 \mathrm{~S}$ rRNA phylotypes in oceanic samples lineage has been detected in other studies either (Giovannoni et al. 1990, Fuhrman et al. 1993, Mullins et al. 1995). It is noteworthy that in bacterial assemblages in limnetic systems including bacterioplankton, lake snow aggregated and activated sludge (Wagner et al. 1993, Alfreider et al. 1996, Glöckner et al. 1996, Weiss et al. 1996, Pernthaler et al. 1998) $\beta$-subclass proteobacteria often comprise large proportions and even dominate

In summary, we have shown that the growth of bacterial communities at the Polar Front, in the ACC, the marginal ice zone and at the shelf ice edge exhibited pronounced differences in the temperature optimum. At the Polar Front facultatively psychrophilic or mesophilic bacterial assemblages dominated and further south obligate psychrophiles. In situ hybridization with rRNA-targeted fluorescent oligonucleotide probes 
showed that the psychrophilic picoplankton had a different composition and was dominated by bacteria of the Cytophaga/Flavobacterium cluster whereas Proteobacteria and Archaea played only a minor role.

Acknowledegments. We would like to thank the crew of the RV 'Polarstern' and our colleagues of the cruise ANT XIII/2 for their excellent cooperation and help on shipboard. We are particularly grateful to V. Smetacek and U. Bathmann, the chief and vice-chief scientists of the cruise, and B. Rosenstock and $K$. Hennes for their invaluable help with measurements during the cruise. U. Bathmann provided the temperature data. We appreciate that A. Neef let us use the oligonucleotide probe ALF968 prior to its publication. This work was supported by grants from the Deutsche Forschungsgemeinschaft awarded to M.S. (Si 360/7-1) and R.A. (Am 73/2-4).

\section{LITERATURE CITED}

Alfreider A, Pernthaler J, Amann R, Sattler B, Glöckner FO, Wille A, Psenner R (1996) Community analysis of the bacterial assemblage in the winter cover and pelagic layers of a high mountain lake by in situ hybridization. Appl Environ Microbiol 62:2138-2144

Amann RI, Krumholz, Stahl DA (1990) Fluorescent oligonucleotide probing of whole cells for deter-minative, phylogenetic, and environmental studies in microbiology. J Bacteriol 172:762-779

Amann RI, Ludwig W, Schleifer KH (1995) Identification and in situ detection of individual microbial cells without cultivation. Microbiol Rev 59:143-169

Autio R (1992) Temperature regulation of brackish water bacterioplankton. Arch Hydrobiol Beih Ergebn Limnol 37: $253-263$

Azam F, Ammerman JW, Cooper N (1981) Bacterioplankton distributional patterns and metabolic activities in the Scotia Sea. Antarct J US 16:164-165

Billen G, Becquevort S (1991) Phytoplankton-bacteria relationship in the Antarctic marine ecosystem. Polar Res 10: $245-253$

Bjornsen PK, Kuparinen J (1991) Determination of bacterioplankton biomass, net production and growth efficiency in the Southern Ocean. Mar Ecol Prog Ser 71:185-194

Bowman JP, McCammon SA, Brown MV, Nicols DS, McMeekin TA (1997) Diversity and association of psychrophilic bacteria in Antarctic sea ice. Appl Environ Microbiol 63:3068-3078

Chin-Leo G, Kirchman DL (1988) Estimating bacterial production in marine waters from the simultaneous incorporation of thymidine and leucine. Appl Environ Microbiol $54: 1934-1939$

Cota GF, Kottmeier ST, Robinson DH, Smith WO Jr, Sullivan CW (1990) Bacterioplankton in the marginal ice zone of the Weddell Sea: biomass, production and metabolic activities during austral autumn. Deep-Sea Res 37:1145-1167

Coveney MF, Wetzel RG (1995) Biomass, production, and specific growth rate of bacterioplankton and coupling to primary production in an oligotrophic lake. Limnol Oceanogr 40:1187-1200

DeLong EF, Wu KY, Prezelin BB, Jovine RM (1994) High abundance of Archaea in Antarctic marine picoplankton. Nature 371:695-697

Ducklow HW, Carlson CA (1992) Oceanic bacterial production. Adv Microb Ecol 12:113-181

Ducklow HW, Kirchman DL, Quinby HL, Carlson CA, Dam
HG (1993) Bacterioplankton carbon cycling during the spring bloom in the eastern North Atlantic Ocean. DeepSea Res 40:245-263

Fuhrman JA, Azam F (1980) Bacterioplankton secondary production estimates for coastal waters of British Columbia, Antarctica, and California. Appl Environ Microbiol 39: 1085-1095

Fuhrman JA, McCallum K, Davis AA (1993) Phylogenetic diversity of subsurface marine microbial communities from the Atlantic and Pacific Ocean. Appl Environ Microbiol 59:1294-1302

Giovannoni SJ, Britschgi TB, Moyer CL, Field KG (1990) Genetic diversity in Sargasso Sea bacterioplankton. Nature 345:60-63

Glöckner FO, Amann R, Alfreider A, Pernthaler J, Psenner R, Trebesius K, Schleifer KH (1996) An in situ hybridization protocol for detection and identification of planktonic bacteria. Syst Appl Microbiol 19:403-406

Harder W, Veldkamp $\mathrm{H}$ (1971) Competition of marine psychrophilic bacteria at low temperatures. Antonie van Leeuwenhoek 37:51-63

Helmke E, Weyland H (1995) Bacteria in sea ice and underlying water of the eastern Weddell Sea in midwinter. Mar Ecol Prog Ser 117:269-287

Hodson RE, Azam F, Carlucci AF, Fuhrman JA, Karl DM, Holm-Hansen $O$ (1981) Microbial uptake of dissolved organic matter in McMurdo Sound, Antarctica. Mar Biol $61: 89-94$

Kang SH, Fryxell GA (1993) Phytoplankton in the Weddell Sea, Antarctica: composition, abundance and distribution in water column assemblages of the marginal ice-edge zone during a ustral spring. Mar Biol 116: 335-348

Karentz D, Spero HJ (1995) Response of a natural Phaeocystis population to ambient fluctuations of UVB radiation caused by Antarctic ozone depletion. J Plankton Res 17: $1771-1789$

Kirchman DL, K'nees E, Hodson RE (1985) Leucine incorporation and its potential as a measure of protein synthesis by bacteria in natural systems. Appl Environ Microbiol 49: 599-607

Kirchman DL, Keil RG, Simon M, Welschmeyer NA (1993) Biomass and production of heterotrophic bacterioplankton in the oceanic subarctic Pacific. Deep-Sea Res 40:967-988

Lochte K, Bjørnsen PK, Mathot S, Becquevort S (1994) Experiments on the effect of temperature $\left(-2^{\circ} \mathrm{C}\right.$ to $\left.+3^{\circ} \mathrm{C}\right)$ on phytoplankton and bacterioplankton production. Rep Polar Res Alfred-Wegener-Institute Polar Mar Res 135: 91-93

Lochte K, Bjørnsen PK, Giesenhagen H, Weber A (1997) Bacterial standing stock and production and their relation to phytoplankton in the Southern Ocean. Deep-Sea Res 44 : $321-340$

Lovell CR, Konopka A (1985) The effects of temperature on bacterial production in a dimictic eutrophic lake. FEMS Microbiol Ecol 31:135-140

Manz W, Amann R, Ludwig W, Wagner $M$, Schleifer $\mathrm{KH}$ (1992) Phylogenetic oligonucleotide probes for the major subclasses of Proteobacteria: problems and solutions. System Appl Microbiol 15:593-600

Manz W, Amann R, Ludwig W, Vancanneyt M, Schleifer KH (1996) Application of a suite of 16S rRNA-specific oligonucleotide probes designed to investigate bacteria of the phylum cytophaga-flavobacter-bacteroides in the natural environment. Microbiol 142:1097-1106

Massana R, Taylor LT, Murray AE, Wu KY, Jeffrey $W H$, DeLong EF (1998) Vertical distribution and temporal variation of marine plankton archaea in the Gerlache Strait, 
Antarctica, during early spring. Limnol Oceanogr 43: $607-616$

Morita RY (1975) Psychrophilic bacteria. Bact Rev 39:144-167

Morris DP, Lewis WR (1992) Nutrient limitation of bacterioplankton growth in Lake Dillon, Colorado. Limnol Oceanogr 37:1179-1192

Mullins TD, Britschgi TB, Krest RL, Giovannoni SJ (1995) Genetic comparison reveals the same unknown bacterial lineages in Atlantic and Pacific bacterioplankton communities. Limnol Ocanogr 40:148-158

Murray AE, Preston CM, Massana R, Taylor LT, Blakis A, Wu $K Y$, DeLong EF (1998) Seasonal and spatial variability of bacterial and archaeal assemblages in the coastal waters near Anvers Island, Antarctica. Appl Environ Microbiol 64:2585-2595

Neef A (1997) Anwendung der in situ Einzelzellidentifizierung von Bakterien zur Populationsanalyse in komplexen mikrobiellen Biozönosen. Doctoral Thesis, Technische Universität München, Munich

Ouverney CC, Fuhrman JA (1997) Increase in fiuorescence intensity of $16 \mathrm{~S}$ rRNA in situ hybridization in natural samples treated with chloramphenicol. Appl Environ Microbiol 63:2735-2740

Pernthaler J, Glöckner FO, Unterholzer S, Alfreider A, Psenner R, Amann R (1998) Seasonal community and population dynamics of pelagic bacteria and archaea in a high mountain lake. Appl Environ Microbiol 64: $4299-4306$

Pomeroy LR, Deibel D (1986) Temperature regulation of bacterial activity during the spring bloom in Newfoundland coastal waters. Science 233:359-361

Putt M, Miceli G, Stoecker. DK (1994) Association of bacteria with Phaeocystis sp. in McMurdo Sound, Antarctica. Mar Ecol Prog Ser 105:1779-1789

Schweitzer B, Simon M (1995) Limiting nutrients for bacterio-

Editorial responsibility: Karin Lochte,

Rostock, Germany plankton growth in a mesotrophic temperate large lake. Microb Ecol 30:89-104

Sherr EB, Sherr BF (1996) Temporal offset in oceanic production and respiration processes implied by seasonal changes in atmospheric oxygers: the role of heterotrophic microbes. Aquat Microb Ecol 11:91-100

Shiah FK, Ducklow HW (1994) Temperature and substrate regulation of bacterial abundance, production and specific growth rate in Chesapeake Bay, USA. Mar Ecol Prog Ser 103:297-308

Simon M, Azam F (1989) Protein content and protein synthesis rates of planktonic marine bacteria. Mar Ecol Prog Ser 51:201-213

Simon M, Wünsch C (1998) Temperature control of bacterioplankton growth in a temperate large and deep mesotrophic lake. Aquat Microb Ecol 16:119-130

Tibbles BJ (1997) Effects of temperature on the relative incorporation of leucine and thymidine by bacterioplankton and bacterial isolates. Aquat Microb Ecol 11:239-250

Wagner M, Amann R, Lemmer H, Schleifer KH (1993) Probing activated sludge with oligonucleotides specific for Proteobacteria: inadequacy of culture-dependent methods for describing microbial community structure. Appl Environ Microbiol 59:1520-1525

Weiss P, Schweitzer B, Amann R, Simon M (1996) Identification in situ and dynamics of bacteria on limnetic organic aggregates (Lake Snow). Appl Environ Microbiol 62: $1998-2005$

Wiebe WJ, Sheldon WM Jr, Pomeroy LR (1992) Evidence for enhanced substrate requirement by marine mesophilic bacterial isolates at minimum growth temperature. Microb Ecol 25:151-159

Wiebe WJ, Sheldon WM Jr, Pomeroy LR (1993) Bacterial growth in the cold: evidence for an enhanced substrate requirement. Appl Environ Microbiol 58:359-364

Submitted: July 3, 1998; Accepted: January 10, 1999 Proofs received from author(s): July 26, 1999 